\title{
CDCA8 Gene
}

National Cancer Institute

\section{Source}

National Cancer Institute. CDCA8 Gene. NCI Thesaurus. Code C126506.

This gene plays a role in the regulation of mitosis. 